Article

\title{
Sustainable and Flipped STEM Education: Formative Assessment Online Interface for Observing Pre-Service Teachers' Performance and Motivation
}

\author{
Jin Su Jeong *(D), David González-Gómez * ${ }^{\mathbb{D}}$ and Félix Yllana Prieto $\mathbb{D}$ \\ Departamento de Didáctica de las Ciencias Experimentales y las Matemáticas, Universidad de Extremadura, \\ Avenida de la Universidad S/N, 10004 Cáceres, Spain; feyllanap@unex.es \\ * Correspondence: jin@unex.es (J.S.J.); dggomez@unex.es (D.G.-G.)
}

Received: 22 September 2020; Accepted: 10 October 2020; Published: 16 October 2020

check for updates

\begin{abstract}
Sustainable science, technology, engineering, and mathematics (STEM) education involves lifelong education in various domains. Active learning strategies are receiving increased attention as an important tool, and particularly online-based formative assessment interfaces, although challenges to their use remain in sustainable and flipped STEM education. In this research, we observed pre-service teachers' (PSTs') performance and motivation in a university STEM course that was planned as a randomized examination of 71 students during a 2017/2018 course with an online interface for sustainable and flipped formative assessment. In terms of PSTs' standardized performance and the motivation effect survey, we gathered and examined the data to observe pre- and post-test results on adaptive assignments. Additionally, feedback from/to instructors and their log records were recorded by the proposed interface. The results demonstrate the PSTs' positive performance and motivation, and the feedback and log records reiterate its positive influence with $98.6 \%$ participation in the sustainable and flipped online formative assessment interface. Consequently, the foremost drawbacks and challenges that current and traditional STEM education are facing are meaningfully reflected by the results obtained. Thus, the platform allows PSTs to be more involved in experimental contexts and validates learning performance, and the motivations effect survey provides a sustainable and active learning methodology for their future profession.
\end{abstract}

Keywords: STEM; formative assessment; sustainability; flipped classroom; adaptive assignment; PSTs; online teaching and learning; feedback

\section{Introduction}

The decade of education for sustainability development (DESD) has demonstrated the current situation of sustainable science, technology, engineering, and mathematics (STEM) education [1,2]. This can help to attain their goals, together with values that require communal awareness and increased lifelong training, involving established instruction in various education settings [1,3-5]. Active learning strategies are required, such as online-based formative assessment interfaces, although they still face challenges in sustainable and flipped STEM education [6-8]. Sterling stated that sustainable and active STEM education provides an instructive experience to increase human knowledge of economic, biological, and collective interdependence, which will lead to transformative instruction [5]. In the pedagogical scene, procedures and purposes of teaching/learning instill abilities, principles, data, and attitudes in learners, which can act as transformative expediters of sustainable and active learning [9-11]. Along with advanced novel information, a sustainable and flipped online-based formative assessment learning interface could be valuable in authentic lifelong learning and STEM education on the basis of various criteria and sub-criteria $[12,13]$. However, sustainable and flipped STEM higher education 
is in the early phase of its development and its applications are few, although it has played a part in transforming organizations by educating pre-service teachers (PSTs) [14,15]. Current studies have provided detailed examinations and arguments for sustainable STEM education via flipped schemes in higher education by adjusting the sustainable systems involved in active learning methods [16-18].

The assessment is a core component for efficient learning and teaching in formal higher education [19]. As a prerequisite, education must be assessment-focused and the cumulative capabilities of students must be established, together with providing opportunities for improvement [19-21]. In the context of computers and mobile devices in the 21st century, online-based testing in higher education has been observed to be a favorable formative assessment practice at the university level [22-24]. Vonderwell et al. recommended that online-based formative assessment learning settings include dissimilar features in combination with face-to-face settings due to the asynchronous characteristic of interactivity for instructors and learners (also known as online applicants) [25]. Feedback is a significant part of the general formative assessment context, and its efficiency exposes the strength of the feedback scheme, as reported in previous studies [19,26-29]. Thus, online-based formative assessment interfaces have potential to be effectively integrated in educational situations as an appropriate tool for continuous and valuable interactions among instructors and learners [30]. Although they have various attributes for supporting learning, these interfaces are receiving little attention in online and web-enhanced higher education [30,31]. Pachler et al. and Wang et al. highlighted the importance of online-based formative assessment interfaces due to the transfer of knowledge and behavior of learners in assessment-focused learning situations [30,31].

Online-based formative assessment interfaces are closely related to student performance, as demonstrated through adaptive assignments and various types of feedback [32,33]. Here, the online-based formative assessment interfaces often specify assignments and tasks adapted to individual students' learning requirements [34]. To improve student learning effectiveness, Wang introduced adaptive assignments and material learning [33]. Haelermans and Ghysels verified the results and the constructive and favorable effect of the methods [35], which were promoted by the modified characteristics of the formative assessment interfaces [35]. Performance can enrich the use of feedback, which is connected to the motivation effect, which is linked to various types of required feedback [32,34]. Few researchers have considered the motivation effect to validate online-based formative assessment interface effectiveness despite previously reported improvements in students' motivation [36,37]. In self-determination theory, Lazowski and Hulleman advocated meta-analyses that can reveal its positive effects on students' performance and motivation effect [37]. Pilli and Aksu found that an online-based formative assessment interface positively influenced students' attitudes [38]. Hunsu et al. identified a positive influence of non-cognitive results via students' reaction toward courses in terms of engagement and interest [39]. Therefore, STEM performance and motivation can verify the effectiveness of an online-based formative assessment interface, since instructors and learners can receive feedback and view the outcome throughout teaching and learning $[29,38,40]$.

In this research, the objectives are to examine PSTs' performance and motivation in a university STEM course using sustainable and flipped education through an online-based formative assessment interface. In a randomized experiment, the PSTs participated in sustainable and flipped formative assessments, together with various assessment videos, on an online interface during a 2017/2018 course. The course comprised a total of 71 students who used a sustainable and flipped formative assessment interface. Based on PSTs' performance and motivation, which were surveyed pre- and post-test along with log records, data were collected and analyzed to obtain results. Feedback and adaptive assignments were received from the instructors using the online-based proposed interface. A flowchart of the research is shown in Figure 1. 


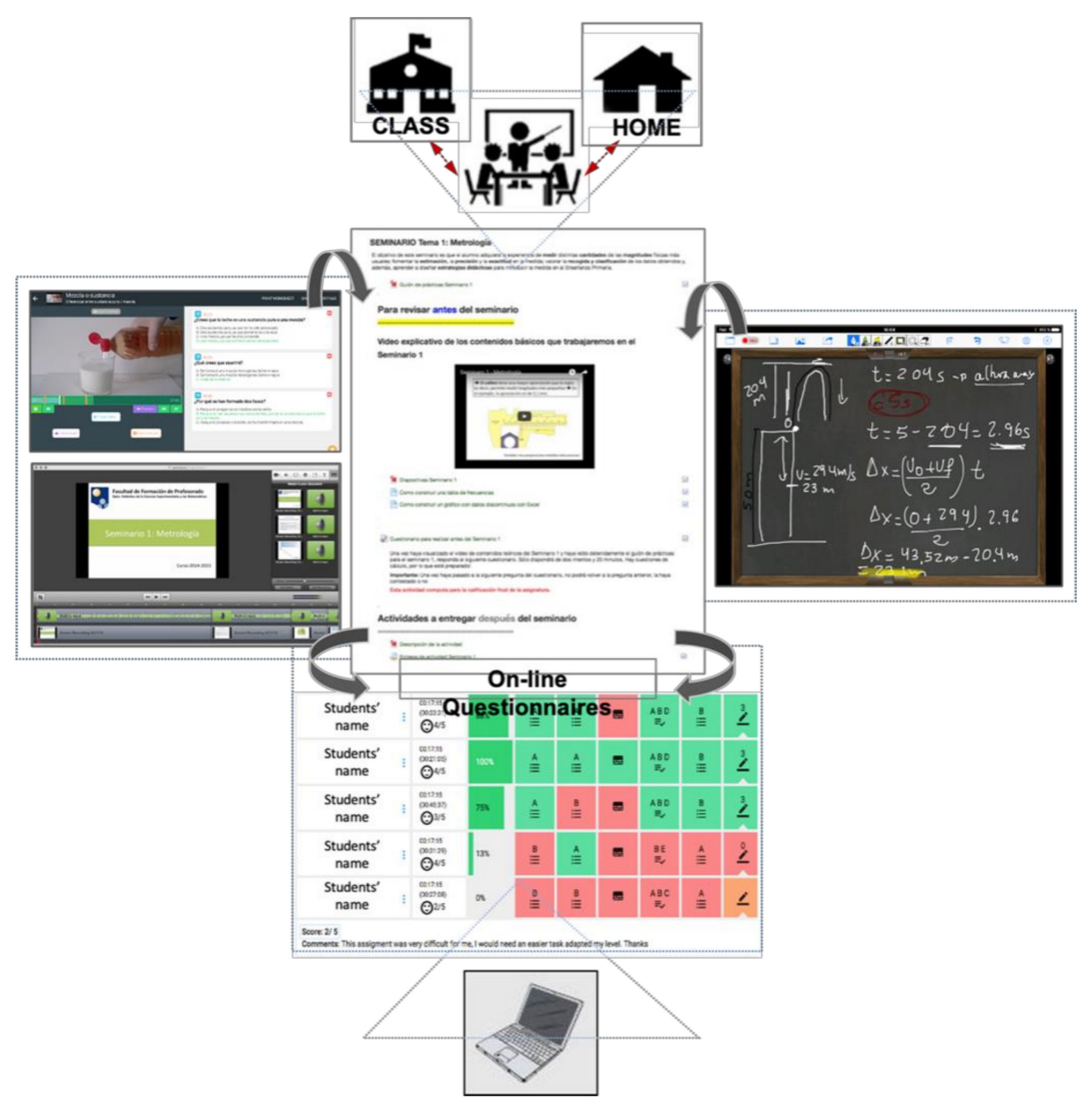

Figure 1. Flowchart of research used to observe PSTs performance and motivation when using an online-based formative assessment interface.

\section{Materials and Methods}

\subsection{Sample}

The online-based formative assessment interface was applied in a sustainable and flipped STEM course on a general primary education science subject. As shown in Table 1, the sample included 71 PSTs that were randomized and analyzed during a 2017/2018 course. The randomization assignment was not prejudiced. With a sustainable and flipped formative assessment interface, the PSTs, who had no prior experience with the interface, participated into two surveys, pre- and post-test, that gathered data about their performance and motivation. PSTs were enrolled in general STEM education for the second year of a post-secondary primary education degree in Spain. Here, PSTs were randomly allotted to either the experimental or waiting condition. The PSTs who did not regularly attend the class were allocated to the waiting condition. In the experimental condition, PSTs used the online-based formative assessment interface over 15 weeks from January to May. Only 1 enrolled PST did not participate, so a total of 70 PSTs participated (98.6\%). Table 1 provides a descriptive analysis of PSTs' data, including total participant number, sex, average age, educational background, and grade point average (GPA) at the pre- and post-test on a 0 to 10 scale. Lastly, PSTs were free to choose to participate in the research without the imposed constraints. 
Table 1. Description of the PSTs in this research.

\begin{tabular}{|c|c|c|}
\hline Variable & & Value \\
\hline Number & & 71 \\
\hline Male (number) & & $28.6 \%(20)$ \\
\hline Female (number) & & $71.4 \%(51)$ \\
\hline Age & & 20.1 \\
\hline \multirow{5}{*}{ Educational Background (number) } & Social sciences & $67 \%(47)$ \\
\hline & Science & $21 \%(15)$ \\
\hline & Arts & $3 \%(2)$ \\
\hline & Technology & $3 \%(2)$ \\
\hline & Others & $6 \%(5)$ \\
\hline Pre-test grade & & 6.93 \\
\hline Post-test grade & & 7.54 \\
\hline
\end{tabular}

\subsection{Course Context}

To measure PST performance and motivation through the online-based formative assessment interface in a sustainable and flipped STEM course setting, the interface was applied into a general STEM course. The class followed a flipped and sustainable paradigm integrated in a Moodle virtual interface that was given to PSTs that had 3 theoretical sessions and 1 laboratory session over 15 weeks in the second semester of second year of a post-secondary degree in primary education.

Table 2 provides the schematic course syllabus of the 2017/2018 course, which is a compulsory subject for all PSTs, who learn the content through a class schedule. Five sections of the course syllabus were organized as theoretical and laboratory content based on content and complexity. Each section contained various class materials such as written resources, flash simulators, and video modules containing the STEM material that PSTs need to complete before the class, and then they have a just-in-time class that includes an online quiz, group discussion, problem sets, and case studies that are used to review content and provide feedback to the instructors. In the laboratory section, the class size was reduced, and various class times were used to adapt the learning environment. Thus, the provided content was accessible for the entire course duration, which allowed PSTs to watch them repetitively. Hence, PSTs in this sustainable and flipped class scenario can be more active and collaborative in the class, which can lead to engagement while in-class time rather than being a passive listener.

Table 2. Schematic of the 2017/2018 course syllabus [41].

\begin{tabular}{|c|c|c|}
\hline \multicolumn{2}{|r|}{ Section Title } & Main Content \\
\hline 1 & $\begin{array}{l}\text { Primary science teaching } \\
\text { and learning }\end{array}$ & $\begin{array}{l}\text { Scientific literacy, primary science education, teaching models, } \\
\text { and resources, techniques, and strategies to instruct science }(19 \mathrm{~h}) \text {. }\end{array}$ \\
\hline 2 & The Universe & $\begin{array}{c}\text { The origin and evolution of the Universe and the solar system in } \\
\text { primary science education }(33.5 \mathrm{~h}) .\end{array}$ \\
\hline 3 & Matter & $\begin{array}{l}\text { The physical and chemical properties of matter, matter interaction } \\
\text { properties, atomic representations, substance and mixture, density, } \\
\text { and mechanics and its fluids }(32 \mathrm{~h}) .\end{array}$ \\
\hline 4 & Matter transformation & $\begin{array}{l}\text { Physical changes, thermodynamics, chemical change/reaction, } \\
\text { and nuclear change/reaction }(33.5 \mathrm{~h}) .\end{array}$ \\
\hline 5 & Energy & $\begin{array}{l}\text { Energy types; energy use, transfer, transformation, conservation, } \\
\text { and degradation; light and sound; electric energy with circuits and } \\
\text { magnetism; and energy in environment and society ( } 32 \mathrm{~h}) .\end{array}$ \\
\hline & Total & $150 \mathrm{~h}$ \\
\hline
\end{tabular}




\subsection{Data Collection and Analysis}

Various instruments for data collection and analysis were used to observe PST performance and motivation: standardized performance assessments, motivation effect survey, and log records of PSTs. To observe PST performance, various assessments were used for the entire course at different moments, including essay, quiz, numerical exercise, final exam, feedback, and adaptive assignments. All assessments, particularly their general grade, were compared with previous performance-i.e., pre- and post-test data-which were assigned values on a 0 to 10 scale. To observe PST motivation, as shown in Table 3, we used a survey regarding motivation toward science after using the online-based formative assessment interface [42,43]. This questionnaire consisted of 20 items through which PSTs could express their feelings toward science based on a five-point Likert scale, where 1 indicated favorable and 5 indicated unfavorable. Here, the scale reliability was tested using Cronbach's $\alpha$. Together with the standardized performance assessments, the survey was also analyzed as pre- and post-test (beginning and end of course, respectively). In both cases, PSTs' log records showed the observation of the intensity of the online-based formative assessment interface. For instance, they are completed assignments, interface utilization minutes, assignment views, etc., which can be retrieved at any time during the course. Here, the instructors can determine what assignment PSTs have a problem proceeding with and then can provide adaptive assignments and feedback on the basis of their characteristics.

Table 3. The 20 questions in three questionnaire sections used to observe PST motivation [44].

\begin{tabular}{|c|c|c|}
\hline Question (Q) & Descriptions & Section \\
\hline Q1 & Science is useful for the problems of everyday life. & View of society about science (SS) \\
\hline Q2 & Science is something that I enjoy very much. & Enjoyment of science (ES) \\
\hline Q3 & I do not perform well in science. & Enjoyment of science (ES) \\
\hline Q4 & Doing science labs or hands-on activities is fun. & Enjoyment of science (ES) \\
\hline Q5 & I feel comfortable in a science class. & Enjoyment of science (ES) \\
\hline Q6 & There is little need for science in most of today's jobs. & View of society about science (SS) \\
\hline Q7 & Science is easy for me. & Enjoyment of science (ES) \\
\hline Q8 & $\begin{array}{l}\text { When I hear the word "science", I have a feeling } \\
\text { of dislike. }\end{array}$ & Enjoyment of science (ES) \\
\hline Q9 & I do not like anything about science. & Enjoyment of science (ES) \\
\hline Q10 & $\begin{array}{l}\text { I feel tense or upset when someone talks to me } \\
\text { about science. }\end{array}$ & Anxiety in science (AS) \\
\hline Q11 & It is important to know science to get a good job. & View of society about science (SS) \\
\hline Q12 & I would like a job that does not use any science. & View of society about science (SS) \\
\hline Q13 & I enjoy talking to other people about science. & Enjoyment of science (ES) \\
\hline Q14 & I enjoy watching science programs on television. & Enjoyment of science (ES) \\
\hline Q15 & I am good at science labs and hands-on activities. & Enjoyment of science (ES) \\
\hline Q16 & $\begin{array}{l}\text { You can get along perfectly well in everyday life } \\
\text { without science. }\end{array}$ & View of society about science (SS) \\
\hline Q17 & Working with science upsets me & Anxiety in science (AS) \\
\hline Q18 & I feel nervous when thinking about doing science. & Anxiety in science (AS) \\
\hline Q19 & It scares me to have to take science class. & Anxiety in science (AS) \\
\hline Q20 & I have good feelings toward science. & Enjoyment of science (ES) \\
\hline
\end{tabular}


To analyze the data collected to observe PSTs' performance and motivation in the sustainable and flipped STEM course, descriptive analysis was applied to depict the most suitable method for labeling and characterizing the data and drawing probable conclusions (Table 1). Then, sample homogeneity was extended to verify the outcomes of the online-based formative assessment interface. Normal distribution was designated through the Shapiro-Wilk normality test to confirm data establishment. If the data were not normally distributed, a non-parametric statistical test was used due to using pre- and post-test as the outcomes. The Mann-Whitney test helped to determine significant differences. Finally, Cronbach's $\alpha$ was used to estimate the survey reliability. The validity of the questionnaire was 0.83 in this test. All participating PSTs were informed of the purpose of research data collection, and if there was a PST who did not participate in the research and/or did not give permission to access their data, their data were not used. The SPSS statistical tool (IBM, New York, NY, USA) was used to analyze the data.

\section{Results}

\subsection{Formative Assessment Tool Description}

Figure 2 shows the online-based formative assessment interface that was used in sustainable and flipped STEM education to observe PSTs performance and motivation in two different environments: PSTs and instructors.

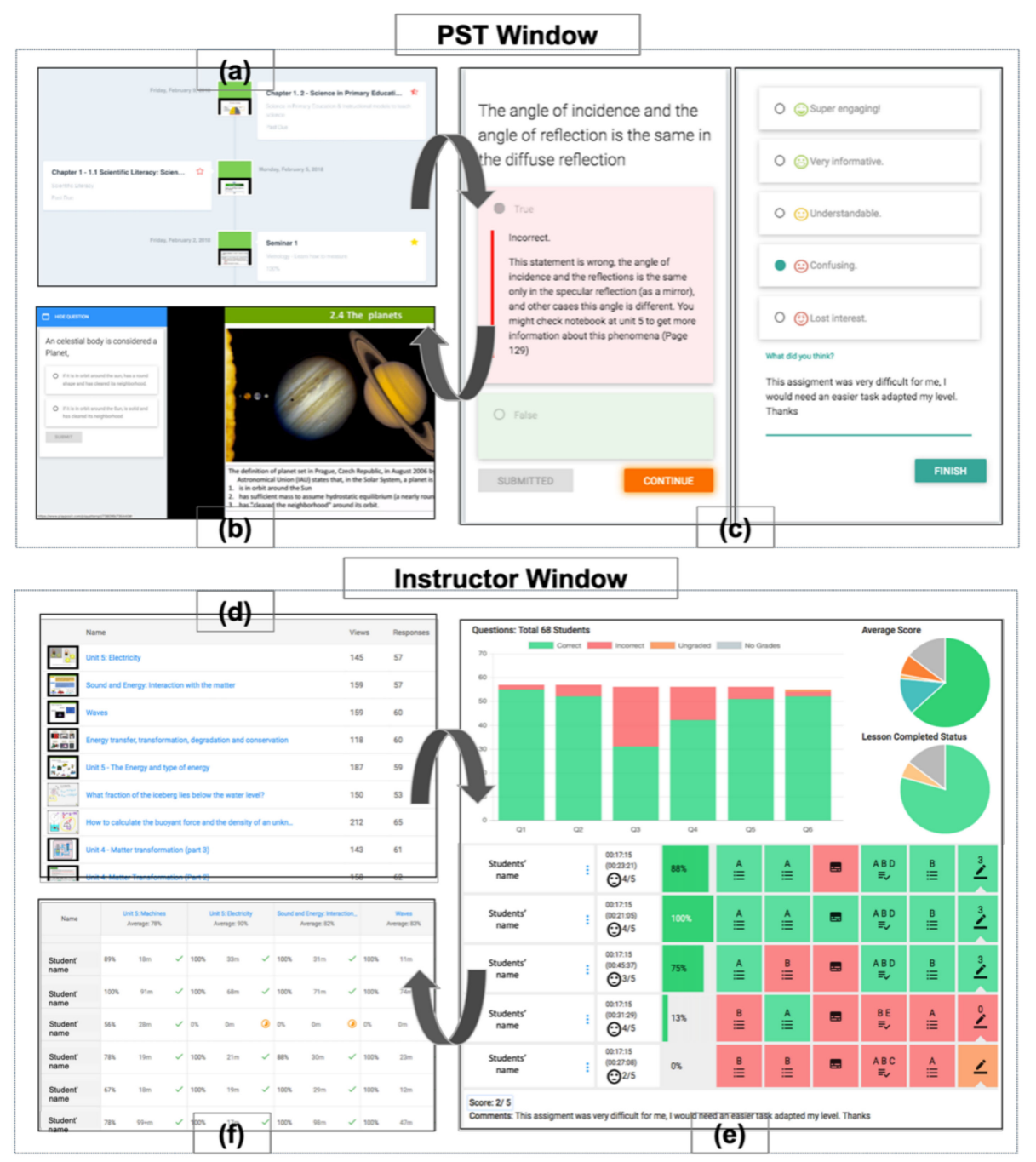

Figure 2. Online-based formative assessment interface for PSTs and instructors. 
First, the PST environment contains an assignment, assignment video, and feedback windows for different lessons, which allow interaction with the instructors. Here, PSTs must register to access all the content of the online-based formative assessment interface and then can access the starting interface that has different lesson assignments scheduled by the instructors (Figure 2a). As shown in Figure 2b, a short video with a 5-10-min duration was provided as an assignment where PSTs were required to watch it and completed the embedded questions. All the assignments must be completed while watching the full video. The videos were enhanced assignments with embedded time-interactivity. As shown in Figure 2c, the interface provides feedback windows after finishing each assignment. Here, PSTs can interact with the instructors through immediate and simple feedback with different colors (green indicates suitable and red indicates unsuitable) when they finish a video assignment. In terms of immediate feedback, PSTs may add some comments to their answers and/or request further explanation from instructors. Therefore, the instructors recalculate and decide upon the required adaptive assignment levels based on the capability and reaction of PSTs to the regular curriculum.

Second, the instructor environment contains overview, monitoring, and PST summary windows in a dashboard. As shown in Figure 2d, the overview window demonstrates all video assignments that were completed by the PSTs. Here, the instructors can check the total number of views and the number of completed views for the assigned videos. In this window, they can also preview assignment videos for each PST. As shown in Figure 2e, the monitoring window depicts the student progress and evolution. Here, the instructors can track an assignment video for both individual PSTs and the entire class. Particularly, the assigned video progress option shows the performance of each PST along with their answer accuracies, feedback, and comments to the instructors. This option shows how a PST acted to achieve their learning goals based on their progress. As shown in Figure 2f, the PST summary window shows each mean outcome summary for the corresponding lessons for all the various assigned videos. Here, the instructors can differentiate PST performance levels along with adaptive assignments, which are delivered via the online-based formative assessment interface on the basis of each PST and assignment characteristics.

\subsection{Observed Results}

Figure 3 indicates the PSTs performance outcomes with the use of the online-based formative assessment interface. Together with various instruments applied, we obtained the mean value for the course indicated. The various instruments used as class assessments included numerical exercises, quizzes, and essays with adaptive assignments, which produced their mean grade. PSTs completed these assignment types in class, which produced a relatively homogenous mean grade, as shown in the figure. In the case of lab assignments, PSTs grades could be divided into three groups: lab diaries, numerical exercises, and lab reports. The final grade for this course, which was provided as a post-test grade as shown in Figure 3, was 70\% final exam grade and 30\% class and lab assignments completed throughout the course. Thus, feedback to PSTs along with adaptive assignments helped them to increase their performance. Here, adaptive assignment quantity positively affected PST performance since they were more focused on their learning needs than actual curriculum assignments. Therefore, PST performance outcomes, after applying the online-based formative assessment interface, that were measured using dissimilar instruments suggested showed the significant positive influence of the interface.

Figure 4 depicts the outcomes of the motivation survey with the use of the online-based formative assessment interface during the 2017/2018 academic year. Here, a survey questionnaire comprised of 20 items was used, where the responses could be provided on a five-point Likert scale, where 1 indicated strongly agree and 5 indicated strongly disagree. The online survey was administered two times: as a pre-test at the beginning course and as a post-test at the end of the course. The PST outcomes were compared using pre- and post-test responses. Amongst the 20 questions, we found a significant difference in 12 questions. These questions were grouped into three classes in which significant differences were perceived, as shown in Figure 4b. Particularly, the online survey outcomes showed 
that the implementation of the online-based formative assessment interface motivated PSTs toward STEM, and this effect was positive and consistent within the course year. The questions were catalogued in three groups: view of society about science (SS), which included questions 1 and 11; enjoyment of science (ES), which included questions 2, 3, 4, 5, 7, 13, 14, 15, and 20; and anxiety about science (AS), which included question 19 [42]. For SS, the outcome analysis indicated that the motivation effect became more positive post-test compared with pre-test. For ES, PSTs anxiety significantly decreased, and the motivation effect significantly increased from pre- to post-test, as shown in Figure 5. Therefore, with a significant positive influence, the outcomes are emphasized in Figure 4, which provides one question for each group as an example.

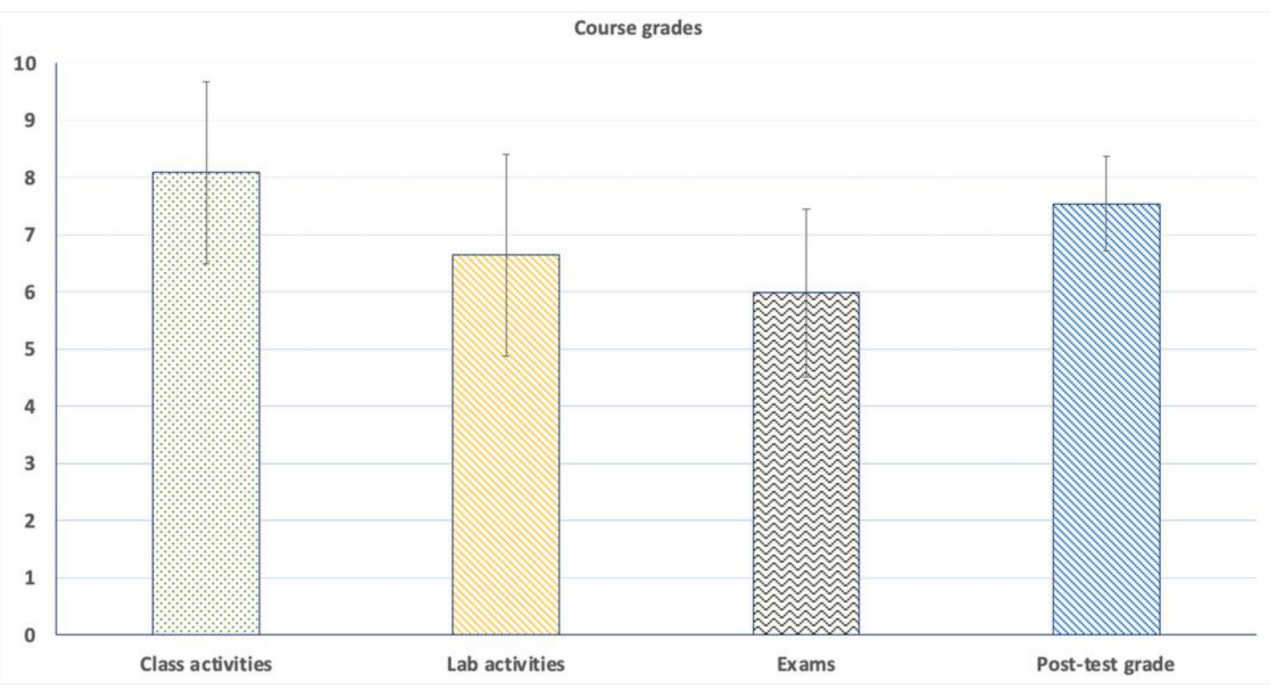

Figure 3. The analysis of PSTs performance once using the proposed interface.

Table 4 describes the log records created by the online-based formative assessment interface of PSTs in sustainable and flipped STEM education. Together with the analysis of performance and motivation, the table shows the PST system interactions, relevant information, and system usage degree. A positive effect on performance and motivation was noted for the videos assigned through the online-based formative assessment interface. The interface contained a total of 28 video assignments with a total duration of $315.07 \mathrm{~min}$ for the course, and the average length of each video assignment was $11.25 \mathrm{~min}$. The average video watching time per PST was $1192 \mathrm{~min}$, which indicated that the PSTs watched the videos more than once. One particular PST used the interface more than the other PSTs. Thus, through the interface, the average views per assignment was 163 times, regardless of the time spent on it. So, we determined the average views per PST, 2.33 times, along with the average views per assignment. In this 2017/2018 course, the average spent time per assignment was $42.5 \mathrm{~min}$. A similar pattern showed that each PST spent more than four times the original video length on each assignment. Therefore, we found that the online-based formative assessment interface helped to improve performance and motivation of PSTs in sustainable and flipped STEM education. 


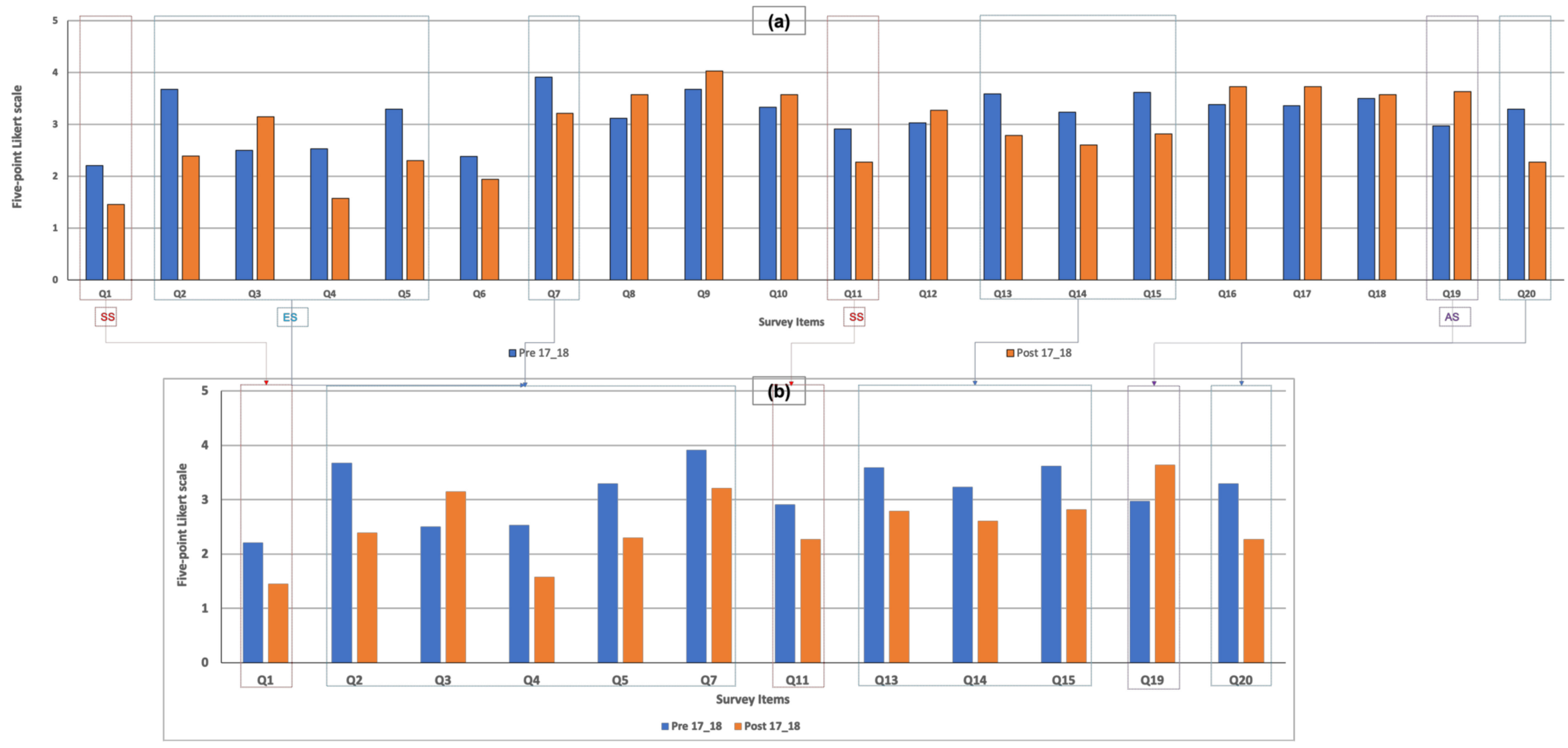

Figure 4. The analysis of motivation effect survey of (a) 20 survey questions and (b) 12 selected questions for pre- and post-test data after applying the interface [42]. 
ES

5

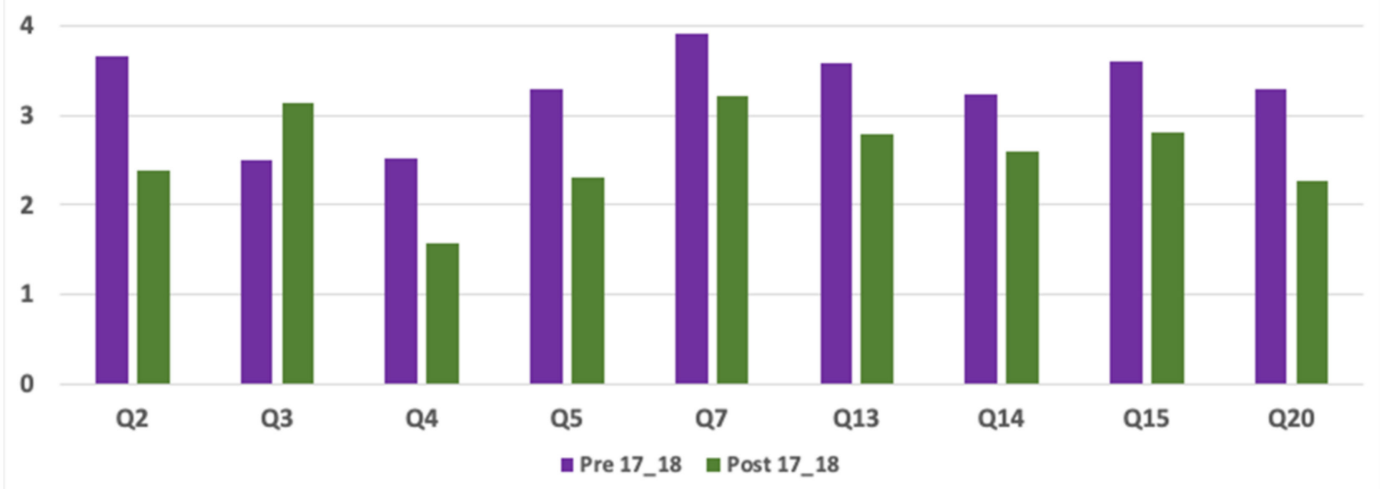

Figure 5. The ES analysis of selected questionnaire between pre- and post-test.

Table 4. Descriptive analysis of the log records from the online-based formative assessment interface.

\begin{tabular}{|c|c|c|}
\hline Description & Unit & Value \\
\hline PST & \multirow{4}{*}{ Number } & 70 \\
\hline Total assignment & & 28 \\
\hline Average views per PST & & 2.33 \\
\hline Average views per assignment & & 163 \\
\hline Assignments completed by PST & $\%$ & 89 \\
\hline Total hour per course & \multirow{4}{*}{ Minutes } & 315.07 \\
\hline Average length per each assignment & & 11.25 \\
\hline Average spent time per assignment & & 42.5 \\
\hline Average time per PST & & 1192 \\
\hline
\end{tabular}

\subsection{Discussion}

The obtained outcomes provided new information that can be considered to monitor PST performance and motivation. The proposed online-based formative assessment interface for specific sustainable and flipped STEM education of PSTs can fill a gap in current traditional teaching methodologies and be used to measure performance and motivation along with log records, feedback, and adaptive assignments.

Although sustainable STEM education is spreading, it is still in an early phase and not enough interfaces and methodologies are available in higher education $[1,2,8]$. In these environments, the goals include increasing public consciousness, engaging in life-long instruction, and increasing knowledge in various instructive areas [1,3-5]. Online-based formative assessment interfaces, as an active learning strategy, are receiving increased attention as an educational tool, although they still face challenges in implementation in sustainable and flipped STEM education [6-8]. Assessments are used to help test the understanding of a concept and the effectiveness of teaching in higher education [19-21]. Thus, online-based formative assessment interfaces have the potential to be integrated in educational situations to enable effective interactions amongst instructors and learners [30]. However, sustainable and flipped STEM education is still in its initial stages and has rarely been applied in real-word settings, although it has been used in various scenarios for educating professionals [14,15]. Current available research discusses in detail the assessment of sustainable and flipped STEM education in higher education in increasing innovation [16-18]. 
In 21st century higher education, with assessment as an essential component, online-based interfaces aided by mobile devices and computers can be used to disseminate assessments [22-24]. Vonderwell et al. recommended that online-based formative assessment learning settings include dissimilar features in parallel with face-to-face settings due to the asynchronous characteristic of interactivity for instructors and leaners-that is, online applicants [25]. Along a similar line of research, Molenaar and Van Campen stated that online-based formative assessment interfaces can be matched in other instructive stages $[45,46]$. In the formative assessment context, feedback is a significant part, and its efficiency exposes the strength of the feedback scheme [19,26-29]. For an online-based formative assessment interface, feedback and adaptive assignments are vital aspects that can indicate performance for a diagnostic valuation. Although it provides essential supporting learning characteristics, these platforms are receiving little attention in online-based and web-enhanced higher education [30,31]. In this context, Pachler et al. and Wang et al. highlighted the importance of online-based formative assessment interfaces for knowledge transfer and learner attitude in assessment-focused learning situations [30,31].

In sustainable and flipped STEM education, PSTs' performance can be visualized using numbers along with adaptive assignments and feedback via online-based formative assessment interfaces [32,33]. Cornelisz et al. demonstrated the influence of adaptive assignments that can be differentiated based on PST performance [47]. For individual PST requirements, online-based formative assessment interfaces repeatedly specify learning adaptive assignments [34]. Wang noted the positive influence of adaptive learning due to its assignments and resources [33]. Additionally, the use of feedback is connected to the motivation effect feedback [32,34]. Using an online-based formative assessment interface, Pilli and Aksu observed a positive influence on students' attitudes [38]. Performance and motivation can verify the effectiveness of these interfaces since instructors and learners can obtain feedback and determine the impact on the teaching and learning progress $[29,38,40]$. Therefore, further research is required on adaptive assignment and feedback efficiency in entire education groups to support this new online-based formative assessment interface $[48,49]$. Thus, the online-based formative assessment interface could have greater effects on various levels of students' performance and motivation, as previously reported [22,48,50-52].

Consequently, this methodology could be employed in future studies to observe PST performance and motivation during sustainable and flipped STEM education in parallel education settings along with required available data. Due to its flexibility, the interface could be used to elucidate other educational extents.

\section{Conclusions}

This paper presented the effects of an online-based formative assessment interface on PST performance and motivation effect during the 2017/2018 academic year in a university STEM course provided as sustainable and flipped education. A total of 71 students were randomly chosen, and the participate rate was $98.6 \%$ in a course that was part of a primary education bachelor's degree in Spain. We observed and measured standardized PST performance and motivation using a pre- and post-test survey in a normal classroom setting. With log records, the intensity of interface usage amongst PSTs and instructors was determined.

The research findings showed that the online-based formative assessment interface can positively influence PSTs' performance and motivation in sustainable and flipped STEM education via diagnostic valuation. If PSTs and instructors are using the interface to a greater extent, the interface could be even further applicable. Particularly, the PSTs can achieve higher sustainable STEM performance and feel more motivated; in the instructors' case, they can differentiate their teaching method using feedback adaptive assignments and log records. Therefore, with the outcomes obtained, traditional STEM education drawbacks can be overcome. The interface can be used to increase PST and instructor communication and improve the PSTs' professionalization in sustainable STEM education. 
Author Contributions: Conceptualization, J.S.J. and D.G.G.; methodology, J.S.J., D.G.-G., and F.Y.P.; software, J.S.J., D.G.-G., and F.Y.P.; validation, J.S.J., D.G.-G., and F.Y.P.; formal analysis, J.S.J., D.G.-G., and F.Y.P.; investigation, J.S.J., D.G.-G., and F.Y.P.; resources, J.S.J., D.G.-G., and F.Y.P.; data curation, J.S.J., D.G.-G., and F.Y.P.; writing-original draft preparation, J.S.J., D.G.-G., and F.Y.P.; writing-review and editing, J.S.J., D.G.-G., and F.Y.P.; visualization, J.S.J., D.G.-G., and F.Y.P.; supervision, J.S.J. and D.G.-G.; project administration, J.S.J. and D.G.-G. All authors have read and agreed to the published version of the manuscript.

Funding: The authors gratefully acknowledge project EDU2016-77007-R (AEI/FEDER, UE) of the Ministry of Science, Innovation and Universities of Spain, and Consejerería de Economía e Infraestructura y FEDER (Projects IB18004 and GR18004) that made this research possible.

Conflicts of Interest: The authors declare no conflict of interest.

\section{References}

1. Segalàs, J.; Ferrer-Balas, D.; Svanstrom, M.; Lundqvist, U.; Mulder, K.F. What has to be learnt for sustainability? A comparison of bachelor engineering education competences at three European universities. Sustain. Sci. 2009, 4, 17-27. [CrossRef]

2. UNESCO. UN Decade of Education for Sustainable Development, 2005-2014: The DESD at a Glance; UNESDOC: New York, NY, USA, 2005.

3. Pavlova, M. Teaching and learning for sustainable development: ESD research in technology education. Int. J. Technol. Des. Educ. 2013, 23, 733-748. [CrossRef]

4. UNESCO. UNESCO Moving forward the 2030 Agenda for Sustainable Development; UNESDOC: New York, NY, USA, 2017.

5. Sterling, S. Sustainable Education: Re-Visioning Learning and Change. Schumacher Briefings; ERIC: Bristol, UK, 2001.

6. González-Gómez, D.; Cañada-Cañada, F.; Jeong, J.S.; Gallego-Picó, A. La enseñanza de contenidos científicos a través de un modelo «flipped»: Propuesta de instrucción para estudiantes del Grado de Educación Primaria. Enseñanza de las Ciencias 2017, 35, 71-87.

7. Jeong, J.S.; González-Gómez, D.; Cañada-Cañada, F. How does a flipped classroom course affect the affective domain toward science course? Interact. Learn. Environ. 2019, 1-13. [CrossRef]

8. Paechter, M.; Maier, B.; Macher, D. Students' expectations of and experiences in e-learning: Their relation to learning achievements and course satisfaction. Comput. Educ. 2010, 54, 222-229. [CrossRef]

9. González-Gómez, D.; Airado Rodríguez, D.; Cañada-Cañada, F.; Jeong, J.S. A comprehensive application to assist in acid-base titration self-learning: An approach for high school and undergraduate students. J. Chem. Educ. 2015, 92, 855-863. [CrossRef]

10. Sterling, S.; Thomas, I. Education for sustainability: The role of capabilities in guiding university curricula. Int. J. Innov. Sustain. Dev. 2006, 1, 349-370. [CrossRef]

11. Zamora-Polo, F.; Corrales-Serrano, M.; Sánchez-Martín, J.; Espejo-Antúnez, L. Nonscientific university students training in general science using an active-learning merged pedagogy: Gamification in a flipped classroom. Educ. Sci. 2019, 9, 297. [CrossRef]

12. Azeiteiro, U.M.; Bacelar-Nicolau, P.; Caetano, F.J.; Caeiro, S. Education for sustainable development through e-learning in higher education: Experiences from Portugal. J. Clean. Prod. 2015, 106, 308-319. [CrossRef]

13. Garrison, R. Theoretical challenges for distance education in the 21st century: A shift from structural to transactional issues. Int. Rev. Res. Open Distance Learn. 2000, 1, 1-17. [CrossRef]

14. Jeong, J.S.; González-Gómez, D.; Cañada-Cañada, F.; Gallego-Picó, A.; Braveo, J.C. Effects of active learning methodologies on the students' emotions, self-efficacy beliefs and learning outcomes in a science distance learning course. J. Technol. Sci. Educ. 2019, 9, 217-227. [CrossRef]

15. Jeong, J.S.; González-Gómez, D.; Cañada-Cañada, F. The study of flipped-classroom for pre-service science teachers. Edu. Sci. 2018, 8, 163. [CrossRef]

16. Lee, J.; Lee, W. The relationship of e-learner's self-regulatory efficacy and perception of e-learning environmental quality. Comput. Hum. Behav. 2018, 24, 32-47. [CrossRef]

17. McVey, M. E-learning and education for sustainability. Int. Rev. Educ. 2016, 62, 117-121. [CrossRef]

18. Bacelar-Nicolau, P.; Caeiro, S.; Martinho, A.; Azeiteiro, U.M.; Amador, F. E-Learning for the environment. The Universidade Aberta (Portuguese open distance university) experience in the environmental sciences Post-Graduate courses. Int. J. Sustain. High Educ. 2009, 10, 354-367. [CrossRef] 
19. Bransford, J.D.; Brown, A.L.; Cocking, R.R. How People Learn: Brain, Mind, Experience, and School; National Academy Press: Washington, DC, USA, 2000.

20. Bennett, R.E. Formative assessment: A critical review. Assess. Educ. 2011, 18, 5-25. [CrossRef]

21. Huang, Y.M.; Lin, Y.T.; Cheng, S.C. An adaptive testing system for supporting versatile educational assessment. Comput. Educ. 2009, 52, 53-67. [CrossRef]

22. Koedinger, K.R.; McLaughlin, E.A.; Heffernan, N.T. A quasi-experimental evaluation of an on-line formative assessment and tutoring system. J. Educ. Comput. Res. 2010, 43, 489-510. [CrossRef]

23. Larreamendy-Joerns, J.; Leinhardt, G. Going the distance with online education. Rev. Educ. Res. 2006, 76, 567-605. [CrossRef]

24. Maier, U.; Wolf, N.; Randler, C. Effects of a computer-assisted formative assessment intervention based on multiple-tier diagnostic items and different feedback types. Comput. Educ. 2016, 95, 85-98. [CrossRef]

25. Vonderwell, S.; Liang, X.; Alderman, K. Asynchronous discussions and assessment in online learning. JRTE 2007, 39, 309-328. [CrossRef]

26. Duit, R.; Treagust, D.F. Conceptual change: A powerful framework for improving science teaching and learning. Int. J. Sci. Educ. 2010, 25, 671-688. [CrossRef]

27. Hattie, J.; Timperley, H. The power of feedback. Rev. Educ. Res. 2007, 77, 81-112. [CrossRef]

28. Jeong, J.S.; González-Gómez, D.; Conde-Núñez, C.M. Examination of students' engagement with R-SPQ-2F of learning approach in flipped sustainable science course. J. Baltic Sci. Educ. 2019, 18, 880-891. [CrossRef]

29. Mory, E.H. Feedback research revisited. In Handbook of Research on Educational Communications and Technology; Jonassen, D., Ed.; Erlbaum Associates: Mahwah, NJ, USA, 2004; pp. 745-783.

30. Pachler, N.; Daly, C.; Mor, Y.; Mellar, H. Formative e-assessment: Practitioner cases. Comput. Educ. 2010, 54, 715-721. [CrossRef]

31. Gutiérrez-Gallego, J.A.; Naranjo Gómez, J.M.; Jaraíz-Cabanillas, F.J.; Ruiz Labrador, E.E.; Jeong, J.S. A methodology to assess the connectivity caused by a transportation infrastructure: Application to the high-speed rail in Extremadura. Case Stud. Tran. Policy 2015, 3, 392-401. [CrossRef]

32. Timmers, C.F.; Braber Van den Broek, J.; Van den Berg, S.M. Motivational beliefs, student effort, and feedback behaviour in computer-based formative assessment. Comput. Educ. 2013, 60, 25-31. [CrossRef]

33. Jeong, J.S.; Ramírez-Gómez, Á.; González-Gómez, D. A web-based scaffolding-learning tool for design students' sustainable spatial planning. Arch. Eng. Des. Mgmt. 2017, 13, 262-277. [CrossRef]

34. Timmers, C.; Veldkamp, B. Attention paid to feedback provided by a computer-based assessment for learning on information literacy. Comput. Educ. 2011, 56, 923-930. [CrossRef]

35. Haelermans, C.; Ghysels, J. The Effect of an Individualized Online Practice Tool on Math Performance-Evidence from a Randomized Field Experiment. 2015. Available online: http://www.tierweb. nl/tier/assets/files/UM/Workingpapers/TIERWP15e01.pdf (accessed on 23 July 2020).

36. González-Gómez, D.; Jeong, J.S. EduSciFIT: A computer-based blended and scaffolding toolbox to support numerical concepts for flipped science education. Educ. Sci. 2019, 9, 116. [CrossRef]

37. Lazowski, R.A.; Hulleman, C.S. Motivation interventions in education: A meta-analytic review. Rev. Educ. Res. 2015, 39, 1-39. [CrossRef]

38. Pilli, O.; Aksu, M. The effects of computer-assisted instruction on the achievement, attitudes and retention of fourth grade mathematics students in North Cyprus. Comput. Educ. 2013, 62, 62-71. [CrossRef]

39. Jeong, J.S.; Ramírez-Gómez, Á. Development of a web graphic model with fuzzy-decision-making Trial and Evaluation Laboratory/Multi-criteria-Spatial Decision Support System (F-DEMATEL/MC-SDSS) for sustainable planning and construction of rural housings. J. Clean. Prod. 2018, 199, 584-592. [CrossRef]

40. Pape, S.J.; Irving, K.E.; Owens, D.T.; Boscardin, C.K.; Sanalan, V.A.; Abrahamson, A.L.; Silver, D. Classroom connectivity in algebra I classrooms: Results of a randomized control trial. Effect. Educ. 2012, 4, 169-189. [CrossRef]

41. Jeong, J.S.; González-Gómez, D.; Cañada-Cañada, F. Students' perceptions and emotions toward learning in a flipped general science classroom. J. Sci. Educ. Technol. 2016, 25, 747-758. [CrossRef]

42. Schruba, A.E. Evaluation of Student Attitude toward Science and Self-Efficacy in a Non-Majors College Biology Course; Texas Christian University: Fort Worth, TX, USA, 2008.

43. Jeong, J.S. Design of spatial PGIS-MCDA-based land assessment planning for identifying sustainable land-use adaptation priorities for climate change impacts. Agric. Syst. 2018, 167, 61-71. [CrossRef] 
44. Kaelin, M.A.; Huebner, W.W.; Nicolich, M.J.; Kimbrough, M.L. Field test of an epidemiology curriculum for middle school students. Am. J. Health. Educ. 2007, 38, 16-31. [CrossRef]

45. De Witte, K.; Haelermans, C.; Rogge, N. The effectiveness of a computer-assisted math learning program. J. Comput. Assist. Learn. 2015, 31, 314-329. [CrossRef]

46. Pacheco, E.; Lips, M.; Yoong, P. Transition 2.0: Digital technologies, higher education, and vision impairment. Internet High. Educ. 2018, 37, 1-10. [CrossRef]

47. Jeong, J.S.; Ramírez-Gómez, Á. A multicriteria GIS assessment to optimize biomass facility sites with parallel environment-A case study in Spain. Energies 2017, 10, 2095. [CrossRef]

48. Shirley, M.L.; Irving, K.E.; Sanalan, V.A.; Pape, S.J.; Owens, D.T. The practicality of implementing connected classroom technology in secondary mathematics and science classrooms. Int. J. Sci. Math. Educ. 2011, 9, 459-481. [CrossRef]

49. Molenaar, I.; Van Campen, C. Learning Analytics in Practice. The Effects of Adaptive Educational Technology Snappet on Students' Arithmetic Skills; Radboud University Nijmegen: Nijmegen, The Netherlands, 2015.

50. Sheard, M.; Chambers, B.; Elliott, L. Effects of Technology-Enhanced Formative Assessment on Achievement in Primary Grammar. 2012. Available online: https://www.york.ac.uk/media/iee/documents/ QfLGrammarReport_Sept2012.pdf (accessed on 11 April 2020).

51. Pozo-Sánchez, S.; López-Belmonte, J.; Moreno-Guerrero, A.J.; López-Núñez, J.A. Impact of educational stage in the application of flipped learning: A contrasting analysis with traditional teaching. Sustainability 2019, 11, 5968. [CrossRef]

52. Pozo-Sánchez, S.; López-Belmonte, J.; Fuentes-Cabrera, A.; López-Núñez, J.A. Gamification as a methodological complement to flipped learning-An incident factor in learning improvement. Multimodal Technol. Interact. 2020, 4, 12. [CrossRef]

Publisher's Note: MDPI stays neutral with regard to jurisdictional claims in published maps and institutional affiliations. 